
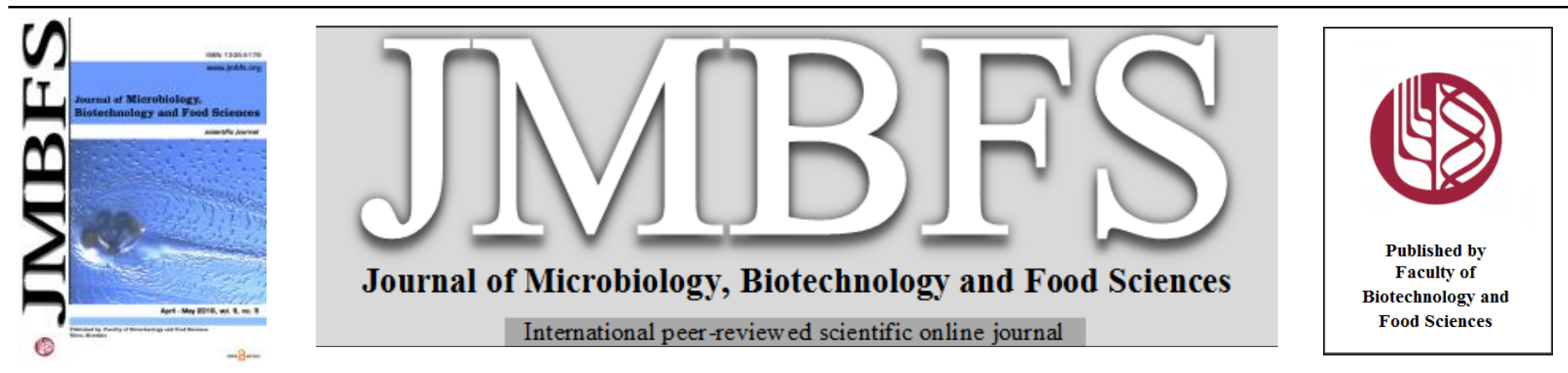

\title{
EXTRACELLULAR SYNTHESIS OF ZINC OXIDE NANOPARTICLES USING ACINETOBACTER SCHINDLERI SIZ7 AND ITS ANTIMICROBIAL PROPERTY AGAINST FOODBORNE PATHOGENS
}

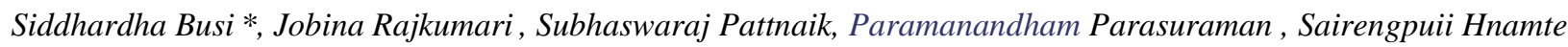 \\ Address(es): Centre for Microbiology, School of Life Sciences, Pondicherry University, Pondicherry - 605014, India. Phone number: +919597761788.
}

*Corresponding author: siddhardha.busi@gmail.com

doi: 10.15414/jmbfs.2016.5.5.407-411

\section{ARTICLE INFO}

Received 24. 6. 2015

Revised 11. 11. 2015

Accepted 18. 12. 2015

Published 1. 4. 2016

Regular article open $\mathcal{O}$ access

\begin{abstract}
The present study focuses on the microbial synthesis of zinc oxide nanoparticles (ZnO NPs) and evaluating the antimicrobial property on foodborne pathogens. The bacterial strain, Acinetobacter schindleri SIZ7 was isolated from the waste filling area of Sivakasi, Tamil Nadu, India. The biogenic synthesis of ZnO NPs was carried out at room temperature and under suitable, eco-friendly environment using culture supernatant of $A$. schindleri. The physico-chemical properties exhibited by the biogenic ZnO NPs were characterised using UV-Visible Spectrophotometry, Energy dispersive X-ray spectroscopy (EDS), High Resolution Transmission Electron Microscopy (HRTEM), Fourier Transformed Infrared spectroscopy (FTIR) and Thermogravitometric Analysis (TGA). The synthesized ZnO NPs are polydispersed and spherical in shape. The antimicrobial activity of $\mathrm{ZnO}$ NPs was investigated against foodborne pathogens, Staphylococcus aureus (MTCC 96), Escherichia coli (MTCC 739), Vibrio parahaemolyticus (MTCC 451) and Salmonella enterica (MTCC 9844). The prepared ZnO NPs exhibited strong antimicrobial activity against $E$. coli and S. enterica with a minimum inhibitory concentration of $100 \mu \mathrm{g} \mathrm{ml}^{-1}$. Thus, the bacterial strain Acinetobacter schindleri SIZ7 could be used for simple, extracellular, nonhazardous and efficient synthesis of antimicrobial ZnO NPs.
\end{abstract}

Keywords: Metallic Nanoparticle, Acinetobacter schindleri, Antimicrobial compounds, 16s rRNA gene, HR-TEM, FTIR, Foodborne pathogens

\section{INTRODUCTION}

Metallic nanoparticles are receiving considerable attention in agriculture and medicine due to their unique physical and chemical properties. Nanoparticles (NPs) are used in the fields of drug delivery, imaging, diagnosis, development of antimicrobial compounds and anticorrosive medical devices (Fayaz et al., 2010 and Martinez-Gutierrez, et al., 2012). Metallic NPs synthesis through bacteria, yeast, fungi, plant biomass, live plants, and plant extracts offer several advantages than chemical and physical route of synthesis (Castro-Longoria $\boldsymbol{e t}$ al., 2011). Even though different biotechnological methods and various biological agents can able to synthesize the metallic nanoparticles, bacteria possess distinctive advantage over others, because of their high generation time and can be easily grown in the laboratory. Among the metallic nanoparticles, researchers reported the synthesized silver and gold nanoparticles using bacteria. The culture supernatants of bacteria like Acetobacter xylinum, Aeromonas sp., Bacillus cereus, Bacillus subtilis, Bacillus licheniformis, Escherichia coli, Enterobacter cloacae, Klebsiella pneumoniae, Lactobacillus acidophilus, Rhodobacter capsulatus, Pseudomonas aeruginosa and Staphylococcus aureus are reported for the synthesis of silver and gold nanoparticles (Shivaji $\boldsymbol{e t}$ al., 2011 and Narayanan et al., 2010).

Zinc oxide nanoparticles ( $\mathrm{ZnO} \mathrm{NPs}$ ) also have gained much interest owing to their wide applications in the preparation of personal care products, coatings and catalysts in environmental remediation, as antifungal and antibacterial agents (Kirthi et al., 2011). Jayaseelan et al., (2012) reported the bacterial mediated synthesis of ZnO NPs using Aeromonas hydrophila and its antimicrobial activity was established. Various researchers reported the antibacterial and antifungal properties of ZnO NPs (Tayel et al., 2011 and Xie et al., 2011). In the scientific literature very few reports are available on extracellular synthesis of $\mathrm{ZnO} \mathrm{NPs}$ using bacteria. Our aim in the present study was to synthesize $\mathrm{ZnO}$ NPs using Acinetobacter schindleri SIZ7 and to investigate their antibacterial activity against foodborne pathogens.

\section{MATERIAL AND METHODS}

\section{Microorganisms}

Pure cultures of bacteria were isolated from soil samples, collected from Sivakasi, Tamilnadu, India by serial dilution technique. The bacteria were screened for the ability to synthesize $\mathrm{ZnO}$ nanoparticles. The bacterial culture, SIZ7 showed rapid synthesis and was maintained on nutrient agar plates. Morphology of the bacteria was observed under scanning electron microscope (SEM). The bacterial isolate was further identified by $16 \mathrm{~S}$ rRNA gene amplification and sequencing. The sequence was amplified using $27 \mathrm{~F}$ forward (AGA GTT TGA TCM TGG CTC AG) and 1492R (TAC GGY TAC CTT GTT ACG ACT T) reverse primers. Phylogenetic tree was constructed using Mega 5.05 software (Kumar et al., 2008). Sequence of SIZ7 was submitted to the NCBI sequence database under the accession number KR135410.1.

\section{Synthesis of ZnO NPs}

The conical flasks (1 litre) containing $500 \mathrm{ml}$ of nutrient broth were inoculated with the bacteria SIZ7 and incubated at $37^{\circ} \mathrm{C}$ for 2 days. The bacterial culture was centrifuged at $1,000 \mathrm{rpm}$ for $10 \mathrm{~min}$ and the cell free supernatant was collected. The supernatant was used with the metal ion solution for bioreduction of metals. Typically $100 \mathrm{ml}$ of bacterial supernatant was brought into contact with $5 \mathrm{mM}$ of zinc nitrate solution. The flasks were agitated for $30 \mathrm{~min}$ and kept on an orbital shaker at $37^{\circ} \mathrm{C}$ for $48 \mathrm{~h}$.

\section{Characterization of ZnO NPs}

The reaction mixture was observed for visual colour change at different time intervals $(4,8,12,16,24,32$, and $48 \mathrm{~h})$. Subsequently the reaction mixture was monitored by UV-Vis spectroscopy $(200-800 \mathrm{~nm})$ as a function of time of reaction. The reaction mixture was subjected to centrifugation at $6,000 \mathrm{rpm}$ and the resultant pellet was collected. The pellet obtained was washed with deionized water for 3 times and the obtained precipitate was dried in a hot air oven at $60^{\circ} \mathrm{C}$ for $6 \mathrm{~h}$. Elemental composition of the NPs was observed by Energy dispersive Xray spectroscopy (EDS). The size and shape of synthesized ZnO NPs was 
determined by using high resolution transmission electron microscopy (JEOL 3010 TEM-HR) equipped with Gatan digital camera, operated at accelerating voltage of $200 \mathrm{kV}$. The capping agent responsible for the stability of nanoparticles and the functional groups associated with NPs was studied by FTIR spectroscopy. FTIR spectra of the samples were measured on Thermo Scientific Nicolet iN-10, spectrophotometer at the resolution of $4 \mathrm{~cm}^{-1}$ in the range of $4000-500 \mathrm{~cm}^{-1}$ in $\mathrm{KBr}$ pellets. The thermal stability and degradation pattern of NPs was determined by Thermogravitometric analysis (TGA) using Thermogravitometric analyzer (Instrument SDT Q600 V20.9 Build 20 Module DSC-TGA Standard).

\section{Antibacterial activity}

The antimicrobial activity of ZnO NPs was tested against the common foodborne pathogenic bacteria, Staphylococcus aureus (MTCC 96), Escherichia coli (MTCC 739), Vibrio parahaemolyticus (MTCC 451) and Salmonella enterica (MTCC 9844) procured from Microbial type culture collection (MTCC), IMTECH, Chandigarh. Antimicrobial activity was carried by well diffusion method according to Jaidev and Narasimha (2010). Briefly, $24 \mathrm{~h}$ active bacterial culture was seeded into nutrient agar medium. A well of $5 \mathrm{~mm}$ was made in the centre of the plate and filled with $150 \mu \mathrm{g} \mathrm{ml}^{-1}$ of $\mathrm{ZnO}$ NPS. The plates were incubated at $37^{\circ} \mathrm{C}$ for $24 \mathrm{~h}$. The zone of inhibition was measured Minimum inhibitory concentration (MIC) of ZnO NPs against the bacterial strains was determined according to Behera et al., (2010). Briefly, test tubes containing $5 \mathrm{ml}$ of Mueller Hinton broth was inoculated with $5 \mathrm{X}^{-7} 0^{-7} \mathrm{CFU} \mathrm{ml}{ }^{-1}$ of bacterial culture and various concentrations of $\mathrm{ZnO}$ NPs $(200,100,50,25$, $12.5,6.25,3.12$ and $1.56 \mu \mathrm{g} \mathrm{ml}^{-1}$ ). The tubes were incubated at $37^{\circ} \mathrm{C}$ for $24 \mathrm{~h}$ with $180 \mathrm{rpm}$ and observed for bacterial growth. Optical density was measured for the same at $600 \mathrm{~nm}$ using UV-Vis Spectrophotometer. All the experiments were performed in triplicate.

\section{RESULTS}

\section{Synthesis and characterization of ZnO NPs}

The bacterial isolate SIZ7 showed $99 \%$ sequence similarity with Acinetobacte schindleri hence named as Acinetobacter schindleri SIZ7 (NCBI GenBank accession no: KR135410.1) (Fig. 1). The analysis of SEM photographs revealed that A. schindleri SIZ7 was rod shaped bacteria (Fig. 2). Extracellular biosynthesis of ZnO NPs was observed by visual colour change, pale yellow to fluorescent yellow after $48 \mathrm{~h}$ of incubation (Fig. 3). UV-Visible spectra of the reaction mixture revealed a characteristic peak between 300 and $360 \mathrm{~nm}$ with a maximum at $310 \mathrm{~nm}$, which is due to the surface plasmon resonance of $\mathrm{ZnO}$ NPs (Fig. 3) and the result is in good agreement with previous reports (Bai et al. 2011). Energy dispersive X-ray spectroscopy (EDS) analysis confirmed the presence of zinc and oxygen (Fig. 4). HRTEM image analysis revealed that $\mathrm{ZnO}$ NPs were polydispersed and spherical in shape (Fig. 5). The HRTEM micrograph suggested that particle diameter ranged from 20 to $100 \mathrm{~nm}$.

FTIR spectrum analysis of ZnO NPs showed intense absorption bands at 3293 2926, 2863, 1732, 1660, 1394 and $1058 \mathrm{~cm}^{-1}$ (Fig. 6). The absorption band observed at $1058 \mathrm{~cm}^{-1}$ represented the $\mathrm{C}-\mathrm{O}-\mathrm{H}$ bending vibrations. The absorption band observed at wave number $1660 \mathrm{~cm}^{-1}$ was identified as amide I band. The absorption bands observed at 1394,2863 and $2926 \mathrm{~cm}^{-1}$ represents the presence of $-\mathrm{CH}_{3}$ group. The absorption band at $1732 \mathrm{~cm}^{-1}$ is characteristic of the $\mathrm{CO}-\mathrm{H}$ stretching. The band around $3293 \mathrm{~cm}^{-1}$ attributes to the $-\mathrm{CONH}_{2}$ group. FT-IR spectral analysis revealed the biological components of the culture supernatant associated with the formation of $\mathrm{ZnO}$ NPs. Thermogravitometric analysis (TGA) measures the weight loss of $\mathrm{ZnO}$ NPs as a function of temperature under a controlled atmosphere (Fig. 7). The synthesized nanoparticles showed good thermal stability. Weight loss at higher temperatures $200^{\circ} \mathrm{C}$ and $400^{\circ} \mathrm{C}$ was $20.31 \%$ and $60.43 \%$ respectively. Water soluble organic compounds secreted extracellularly by bacteria may act both as reducing and stabilizing agents in the green synthesis of $\mathrm{ZnO}$ NPs.

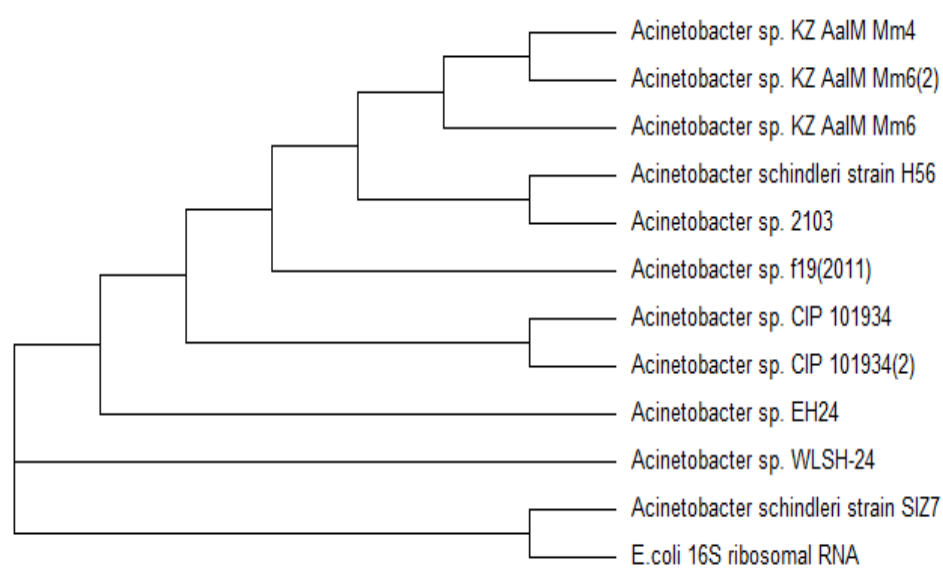

Figure 1 Phylogenetic tree showing genetic relationship between the isolate $A$ schindleri SIZ7 and other closely related reference bacteria.

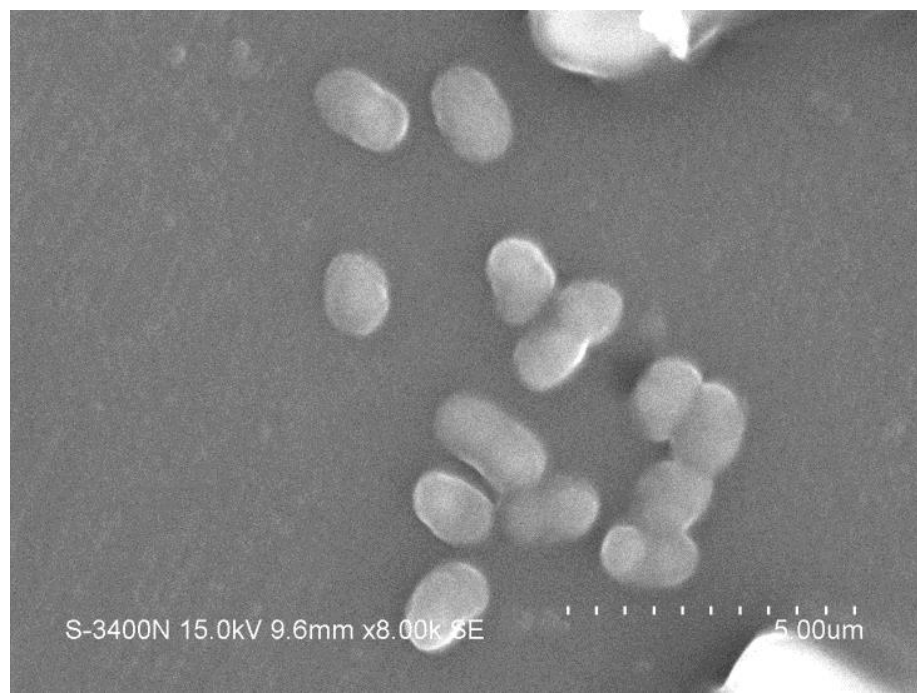

Figure 2 Scanning electron micrograph of Acinetobacter schindleri SIZ7

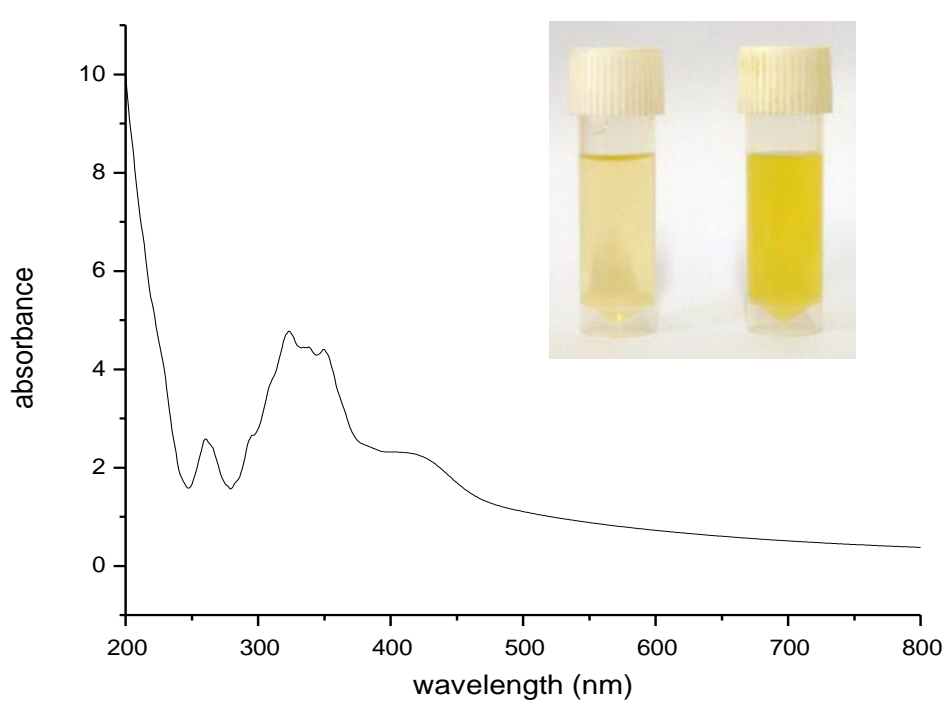

Figure 3 UV-visible spectra of bacterial filtrate as a function of time.. The peak at $310 \mathrm{~nm}$ corresponds to the surface plasmon resonance of

ZnO NPs. Inset shows the corresponding colour change. 


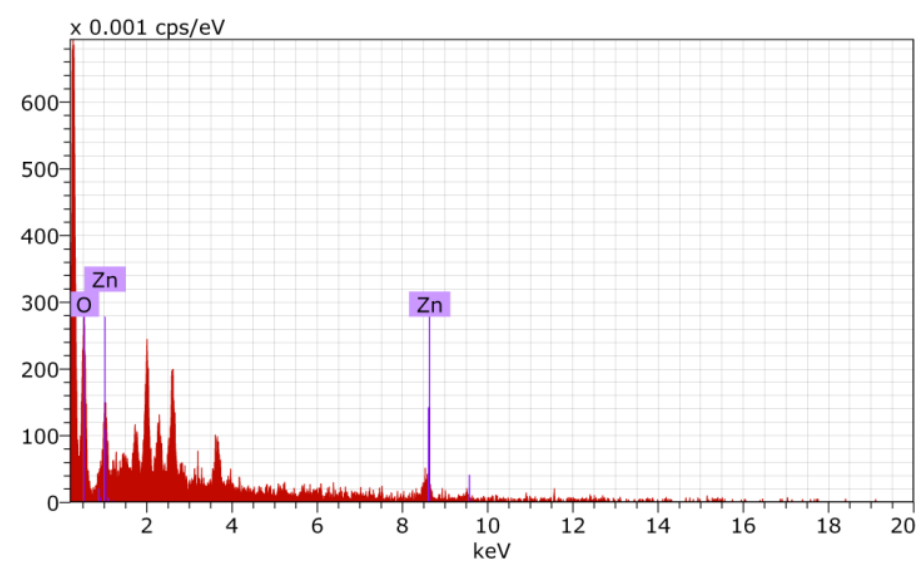

Figure 4 Energy dispersive X-ray (EDS) spectrum of ZnO NPs.

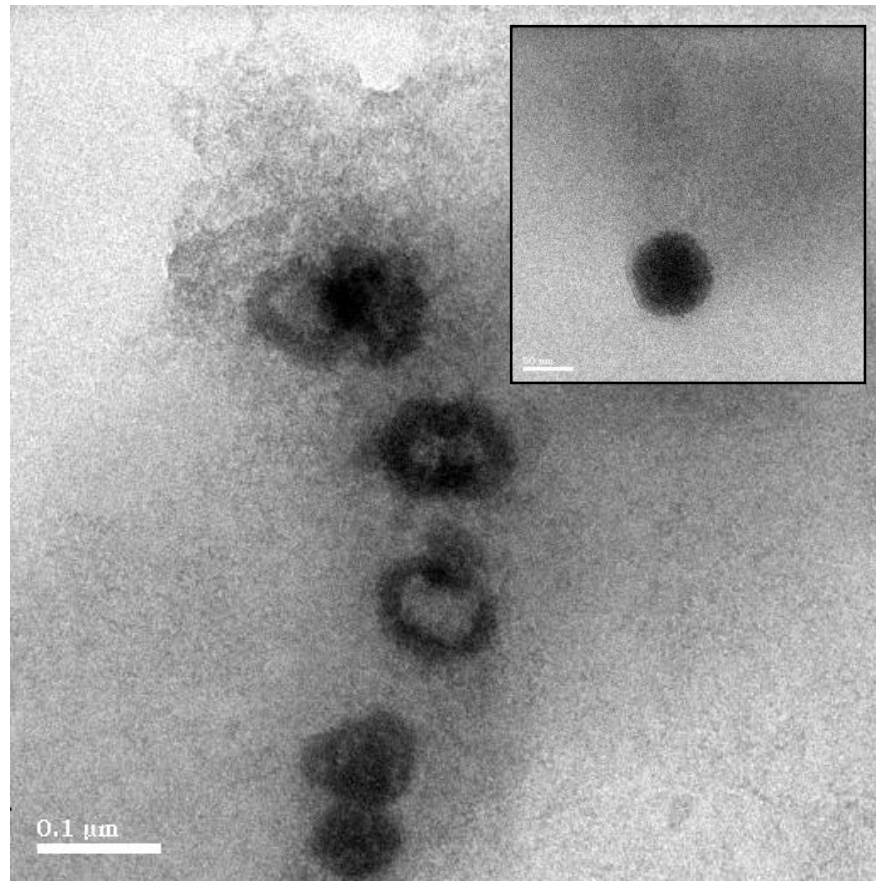

Figure 5 HR-TEM image of ZnO NPs produced by A. schindleri SIZ7

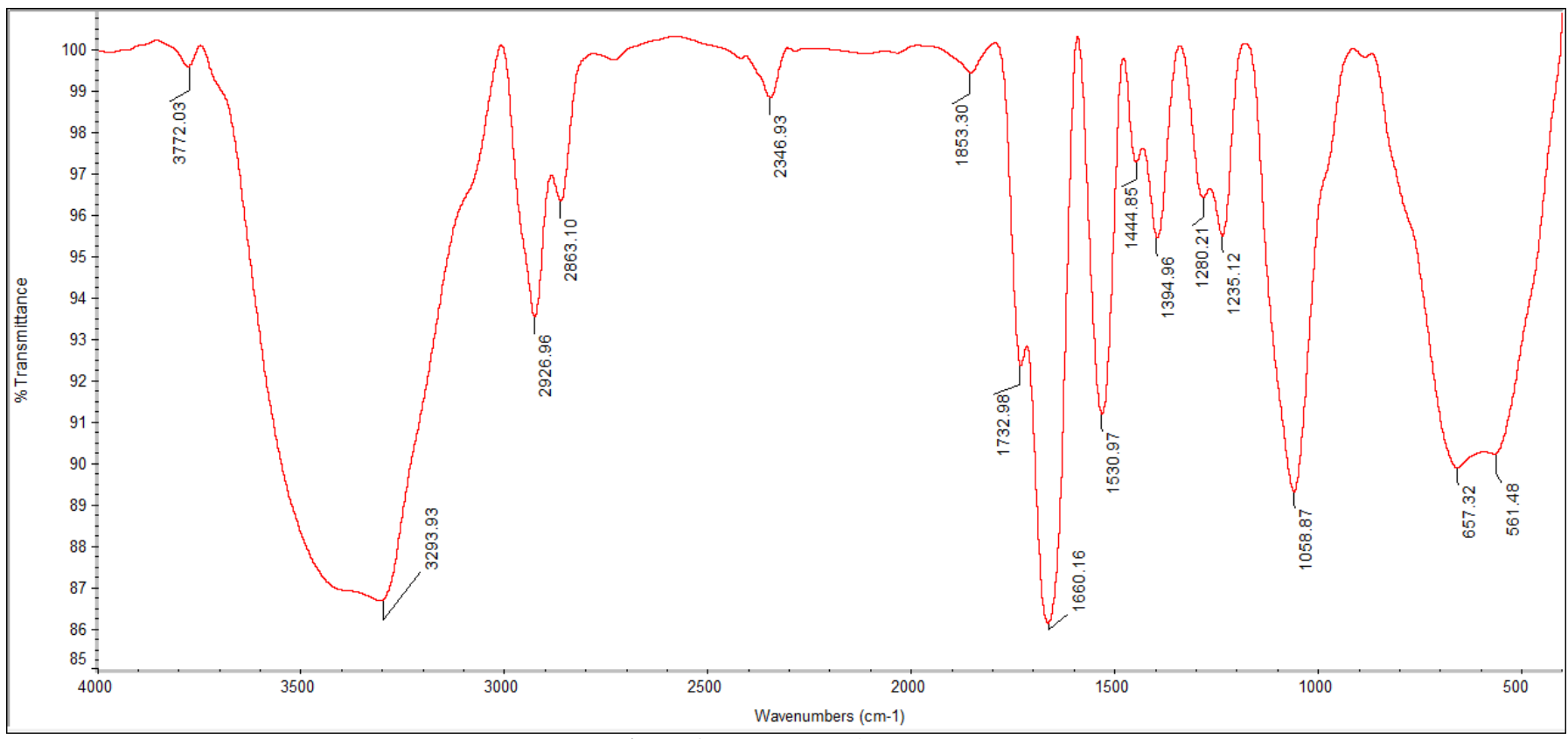

Figure 6 FTIR spectra of $\mathrm{ZnO} \mathrm{NPs}$

\section{Antibacterial activity}

The $\mathrm{ZnO}$ NPs exhibited the antibacterial activity against the common foodborne bacteria tested. At a concentration of $150 \mu \mathrm{g} \mathrm{ml}^{-1}$ the zone of inhibition diameters were 16, 18, 16 and $20 \mathrm{~mm}$ against Staphylococcus aureus (MTCC 96), Escherichia coli (MTCC 739), Vibrio parahaemolyticus (MTCC 451) and Salmonella enterica (MTCC 9844) respectively. The MIC values of $\mathrm{ZnO}$ NPs against tested pathogens were in the range of $100-200 \mu \mathrm{g} \mathrm{ml}^{-1}$. The MIC value of $\mathrm{ZnO}$ NPs against $E$. coli and $S$. enterica was $100 \mu \mathrm{g} \mathrm{ml}^{-1}$. The bacterial strains, $S$. aureus and $V$. parahaemolyticus are less sensitive to $\mathrm{ZnO}$ NPs, MIC value of $200 \mu \mathrm{g} \mathrm{ml}^{-1}$ (Table 1).

Table 1 Antimicrobial activity of ZnO NPs synthesized by A. schindleri SIZ7.

\begin{tabular}{lccc}
\hline Bacteria & $\begin{array}{c}\text { Zone of inhibition } \\
(\mathbf{i n ~} \mathbf{~ m m})\end{array}$ & $\begin{array}{c}\mathbf{M I C} \\
\left(\mu \mathbf{g ~ m l}^{-1}\right)\end{array}$ & $\begin{array}{c}\mathbf{M B C} \\
\left(\mu \mathbf{g ~ m l}^{-1}\right)\end{array}$ \\
\hline S. aureus & 16 & 200 & 400 \\
E. coli & 18 & 100 & 200 \\
V. parahaemolyticus & 16 & 200 & 400 \\
S. enterica & 20 & 100 & 200 \\
\hline
\end{tabular}


(2011) investigated antibacterial effect of zinc oxide $(\mathrm{ZnO})$ nanoparticles on Campylobacter jejuni and suggested that the antibacterial mechanism of $\mathrm{ZnO}$ nanoparticles is most likely due to disruption of the cell membrane and oxidative stress in Campylobacter. Anticandidal activity of $\mathrm{ZnO}$ NPs against $C$. albicans is also correlated with reactive oxygen species (ROS) production (Shoeb et al., 2013). The mechanism of the inhibitory effects of $\mathrm{ZnO}$ NPs on foodborne pathogens might be similar to previous reports.
Due to their potent antimicrobial activity against bacterial strains, researchers focused their investigations more on the synthesis and evaluation of mechanism of antimicrobial activity of $\mathrm{ZnO}$ NPs against an array of pathogenic bacteria.

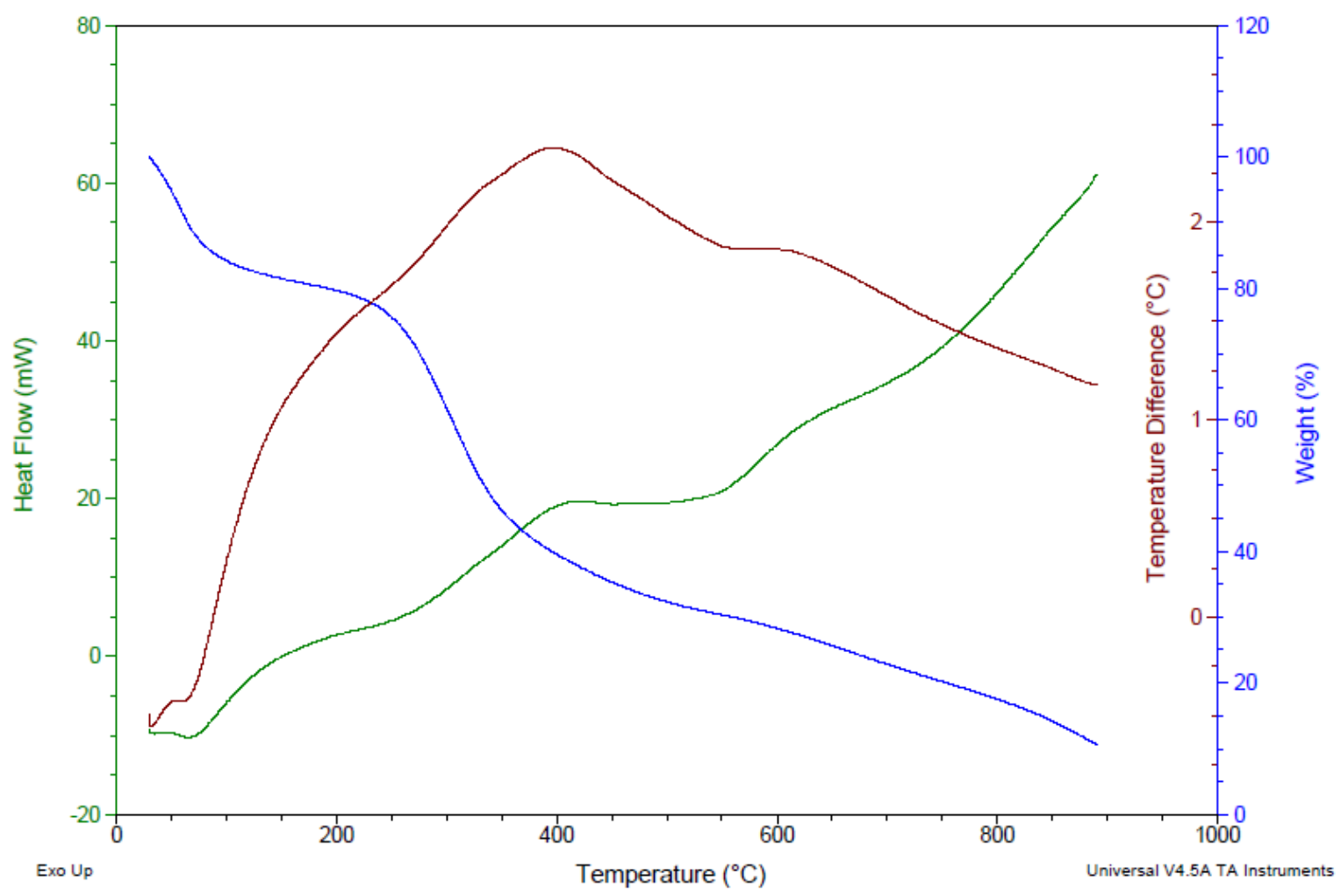

Figure 7 Thermogravitometric analysis of synthesized ZnO NPs

\section{CONCLUSION}

Antimicrobial $\mathrm{ZnO}$ NPs were produced with culture supernatant of A. schindleri SIZ7. The formation of $\mathrm{ZnO}$ NPs was observed, achieved after $48 \mathrm{~h}$ of incubation with culture supernatant. The ZnO NPs formed were spherical in shape and polydispersed with diameters of 20-100 $\mathrm{nm}$. The properties of ZnO NPs were confirmed by HR-TEM, EDS, FTIR and TGA analysis. The ZnO NPs exhibited potential antimicrobial activity against foodborne pathogens, E. coli and $S$ enterica with a MIC of $100 \mu \mathrm{g} \mathrm{ml}^{-1}$. The bacterial system, therefore, has the potential for low-cost and environmentally friendly production of antimicrobia ZnO NPs.

Acknowledgments: The authors thank Pondicherry University for providing necessary facilities. We acknowledge the support extended by Central Instrumentation Facility, Pondicherry University in analyzing the samples by TEM.

\section{REFERENCES}

BAI, S., HU, J., LI, D., LUO, R., CHEN, A., LIU, C.C. 2011. Quantum-sized $\mathrm{ZnO}$ nanoparticles: Synthesis, characterization and sensing properties for NO2. $J$. Mater. Chem. 21, 12288-12294. http://10.1039/C1JM11302J

BEHERA, B., MATHUR, P., DAS, A., KAPIL, A., GUPTA, B., BHOI, S., FAROOQUE, K., SHARMA, V., MISRA, M.C. 2010. Evaluation of susceptibility testing methods for polymyxin. Int. J. Infect. Dis. 14(7):596-601. http:// 10.1016/j.ijid.2009.09.001

CASTRO-LONGORIA, E., VILCHIS-NESTOR, A.R, AVALOS-BORJA, M 2011. Biosynthesis of silver, gold and bimetallic nanoparticles using the filamentous fungus Neurospora crassa. Colloids Surf B Biointerfaces. 83(1):4248. http://10.1016/j.colsurfb.2010.10.035

FAYAZ, A.M., BALAJI, K., GIRILAL, M., YADAV, R., KALAICHELVAN, P.T., VENKETESAN, R. 2010. Biogenic synthesis of silver nanoparticles and their synergistic effect with antibiotics: a study against gram-positive and gramnegative bacteria. Nanomedicine. 6(1):103-9. http://10.1016/j.nano.2009.04.006 JAIDEV, L.R., NARASIMHA, G. 2010. Fungal mediated biosynthesis of silver nanoparticles, characterization and antimicrobial activity. Colloids Surf B Biointerfaces. 81(2):430-433. http://10.1016/j.colsurfb.2010.07.033

JAYASEELAN, C., RAHUMAN, A.A., KIRTHI, A.V., MARIMUTHU, S., SANTHOSHKUMAR, T., BAGAVAN, A., GAURAV, K., KARTHIK, L.,
RAO, K.V. 2012. Novel microbial route to synthesize $\mathrm{ZnO}$ nanoparticles using Aeromonas hydrophila and their activity against pathogenic bacteria and fungi. Spectrochim Acta A Mol Biomol Spectrosc. 90, 78-84 http://10.1016/j.saa.2012.01.006

KIRTHI, A.V., RAHUMAN, A.A., RAJAKUMAR, G., MARIMUTHU, S. SANTHOSHKUMAR, T., JAYASEELAN, C., VELAYUTHAM, K. 2011. Acaricidal, pediculocidal and larvicidal activity of synthesized $\mathrm{ZnO}$ nanoparticles using wet chemical route against blood feeding parasites. Parasitol Res. 109(2):461-472. http://10.1007/s00436-011-2277-8

KUMAR, S., NEI, M., DUDLEY, J., TAMURA, K. 2008. 'MEGA: a biologist centric software for evolutionary analysis of DNA and protein sequences'. Brief. Bioinf. 9,299-306. http://10.1093/bib/bbn017

MARTÍNEZ-GUTIERREZ, F., THI, E.P., SILVERMAN, J.M., DE OLIVEIRA, C.C., SVENSSON, S.L., VANDEN HOEK, A., SÁNCHEZ, E.M., REINER, N.E., GAYNOR, E.C., PRYZDIAL, E.L., CONWAY, E.M., ORRANTIA, E., RUIZ, F., AV-GAY, Y., BACH, H. 2012. Antibacterial activity, inflammatory response, coagulation and cytotoxicity effects of silver nanoparticles. Nanomedicine. 8(3):328-336. http://10.1016/j.nano.2011.06.014

NAGARAJAN, S., ARUMUGAM KUPPUSAMY, K. 2013. Extracellular synthesis of zinc oxide nanoparticle using seaweeds of gulf of Mannar, India. $J$ Nanobiotechnology. 3,11:39. http://10.1186/1477-3155-11-39

NARAYANAN, K.B., SAKTHIVEL, N. 2010. Biological synthesis of metal nanoparticles by microbes. Adv Colloid Interface Sci. 156(1-2):1-13 http://10.1016/i.cis.2010.02.001

OSAMU YAMAMOTO. 2001. Influence of particle size on the antibacterial activity of zinc oxide. International Journal of Inorganic Materials. 3:(7), 643646. http://10.1016/S1466-6049(01)00197-0

SANGEETHA, G., RAJESHWARI, S., VENKATESH, R. 2011. Green synthesis of zinc oxide nanoparticles by aloe barbadensis miller leaf extract: Structure and optical properties. Mater. Res. Bull. 46, 2560-2566. http://10.1016/j.materresbull.2011.07.046

SARKAR, J., GHOSH, M., MUKHERJEE, A., CHATTOPADHYAY, D. ACHARYA, K. 2014. Biosynthesis and safety evaluation of $\mathrm{ZnO}$ nanoparticles Bioprocess Biosyst Eng. 37(2):165-71. http://10.1007/s00449-013-0982-7

SHIVAJI, S., MADHU, S., SINGH, SHASHI. (2011). Extracellular synthesis of antibacterial silver nanoparticles using psychrophilic bacteria. Process Biochemistry. 46(9):1800-1807. http://10.1016/j.procbio.2011.06.008

SHOEB, M., BRAJ, R.S., JAVED, A.K., WASI, K., BRAHMA, N.S. (2013) ROS-dependent anticandidal activity of zinc oxide nanoparticles synthesized by 
using egg albumen as a biotemplate. Adv Nat Sci Nanosci Nanotechnol. 4: 035015 (11pp). http://10.1088/2043-6262/4/3/035015

SIRELKHATIM, A., MAHMUD, S., SEENI, A., KAUS, N. H. M., ANN, L. C., BAKHORI, S. K. M., MOHAMAD, D. 2015. Review on Zinc Oxide Nanoparticles: Antibacterial Activity and Toxicity Mechanism. Nano-Micro Letters, 1-24. http://10.1007/s40820-015-0040-x

TAYEL, A. A., EL-TRAS, W. F., MOUSSA, S., EL-BAZ, A. F., MAHROUS,

H., SALEM, M. F., BRIMER, L. 2011. Antibacterial action of zinc oxide nanoparticles against foodborne pathogens. Journal of Food Safety. 31,211-218. http://10.1111/j.1745-4565.2010.00287.x

XIE, Y., HE, Y., IRWIN, P.L., JIN, T., SHI, X. 2011. Antibacterial activity and mechanism of action of zinc oxide nanoparticles against Campylobacter jejuni. Appl Environ Microbiol. 77(7):2325-2331.http:// 10.1128/AEM.02149-10 